SHS Web of Conferences 23, 04002 (2016)

DOI: $10.1051 /$ shsconf/ 20162304002

(C) Owned by the authors, published by EDP Sciences, 2016

\title{
3R PRACTICES AMONG MOE PRESCHOOL PUPILS THROUGH THE ENVIRONMENTAL EDUCATION CURRICULUM
}

\author{
Hanifah, Mahat and Mohamad Suhaily Yusri, Che Ngah \\ Geography \& Environmental Department, Faculty of Human Sciences \\ Universiti Pendidikan Sultan Idris, Tanjung Malim, Perak Malaysia \\ Corresponding Author: mzuhani@gmail.com
}

\begin{abstract}
Education is the key to increasing the knowledge and awareness of the general public on environmental issues at early ages, as envisaged in the concept of sustainable development. Hence, this study aims to discuss the sustainability practices among children at a Ministry of Education (MOE) pre-school as a result of the implementation of environmental education through a formal curriculum. Sustainability practices of pupils in this study involves the concept of Reduce, Reuse and Recycle. Survey methods were used, which involved 500 pupils in MOE preschools in Hulu Langat district, Selangor Malaysia. Results showed that pre-school pupils practice the 3Rs only at a moderate level while the level of knowledge of sustainability was at a high level. The results also showed that there was no significant relationship between prolonged knowledge in practicing the 3 Rs among pre-school students. Obviously the input given by the teacher in teaching and learning science was not aligned with sustainability activities such as the 3 Rs. Space conservation practices using a structured curriculum platform should be utilised in order to produce citizens who are aware of sustainable development.
\end{abstract}

Keywords: education for sustainable development, awareness, practice, Reduce, Reuse and Recycle

\section{INTRODUCTION}

Environmental management is very important in the context of ensuring the quality of human life. However, the human greed to pursue modernisation has led to environmental quality increasingly being damaged, due to the imbalance of ecological systems via global warming, air pollution, ozone layer depletion, deterioration of water quality, reduction of natural resources and the improvement of solid waste. Given such circumstances, education is an accurate method for producing a generation who have the knowledge and awareness of sustainability (Hopkins \& McKeown, 2002; Joshi, 2009; Moroye, 2005; Sterling, 2003; Scoullos \& Malotidi, 2004). This means that education is the biggest agent of change in the behaviour of society. In fact, education is also considered important because, through the process of individual learning or a more intellectual society, being active, understanding and being able to identify the good and the bad will be born (Hanifah, 2013; Mohmadisa \& Suhaily, 2010). 
Accordingly, Education for Sustainable Development (UNESCO, 2005) was formed to develop all aspects of learning and encourage behavioural change for a sustainable society. At the same time, it aims to integrate the principles, goals or values and practices of sustainable development into all aspects of education with the aim of addressing social issues, economics, culture and ecology in the 21 st century and promoting behavioural change to improve living standards worldwide (Salonen \& Tast, 2013). Thus, the basic construction of knowledge, attitudes and values of sustainable development must be constructed starting at an early age, because children are seen as competent individuals who can form their own identity and life (Samuelsson, 2011). In fact, Siraj-Blatchford (2009) also recognises that early childhood education plays an important role in achieving sustainable development.

Thus, exposure and early education in preschool and kindergarten is an important approach to ensure the effectiveness of education and achieve balanced human capital standards. Agut et al. (2014) found that early childhood education should be considered as a first step towards learning to live in a sustainable manner. Consequently, the implementation of sustainability practices through the National Preschool Curriculum Standard (PCS) is a consistent effort (Ministry of Education, 2010). In PSK there are six pillars of learning that must be achieved: communication, spirituality, attitudes and values, humanities, science and technology. From these six pillars, two focus on the environment, the backbone of humanity, and science and technology. In this case, pre-school teachers play a very important role. This is because they are the executors and a group that is directly involved in the successful implementation of PCS through teaching and learning in the classroom, whether via formal or informal methods. The fact is that it must be recognised if a child is not applying elements of caring and is not in touch with nature, in which case a love of the environment will not be established (Aini \& Laily, 2010).

Therefore this study aimed to take research knowledge and the practice of pre-schoolers in terms of the 3R KPM educational outcomes and exposures received directly at school into account. The findings of this study will provide a true picture of $3 \mathrm{R}$ practices and indirectly contribute to early childhood education from the environmental aspects of sustainability, especially the extent to which actual practice of these children.

\section{LITERATURE}

Education on sustainability studies is generally still limited and this is recognised by Davis (2009), but in some countries there is a significant tendency to study it in depth. Johansson (2009) states that there are aspects of sustainable development in preschool learning. Hägglund and Samuelsson (2009) discuss the policies affecting education, especially in the pedagogical aspects of aiming to foster delivery of preschool children in a more sustainable manner. Reviews by Agut et al. (2014) conclude that the elements for sustainable development should be absorbed in early childhood education with a comprehensive offering that begins with the preparation of the curriculum, teachers being given knowledge and training, and the involvement of community members, especially parents. Greater education at an early age can cause changes towards sustainable development. 
The importance of the existence of the Centre for Education in Early Childhood is a starting point towards lifelong learning and must be seen from a positive perceptive. From birth to 6 years old children experience the stages of the learning process, but the implementation of ESD efforts are not implemented at this level (Tilbury, Stevenson, Fein and Schreuder, 2005). Education in sustainable development should start as early as pre-school as this age group can already show responsibility and care about the lives of others. Apart from the responsibility for achieving sustainable development in the three domains (social, economic and environmental), schools must also expose the elements of continuity in the form of sustainable schools. In addition to promoting environmental awareness, the schools should directly implement social and economic elements (UNESCO, 2012).

Louv (2005) says that children who play and have direct contact with the natural environment are more balanced and healthy. Even the schools that have implemented environmental education through their curriculum will produce children who show improvement in tests and an increased level of enthusiasm to learn something (Ernst, 2007; Glenn, 2000; Lieberman \& Hoody, 1998). Studies also show that a positive experience in nature is the starting point whereby this group can increase their knowledge, awareness of the environment and consequently form good behavior towards the environment as adults (Chawla, 1999; Palmer, 1995; Palmer, Suggate, Najd \& Tsaliki, 1998).

\section{R Practices among Children}

Waste management is the mechanism used to reduce environmental pollution, particularly solid waste. Sustainable waste management is often known as the 3Rs: Reduce, Recycle, and Reuse (Siti Aminah, Rainah \& Annmarie, 2009). The Environmental Protection Agency (EPA, 2007) defines waste reduction as the design and manufacture of materials that can be reduced in quantity or toxicity before consumer purchase or use. This practice is also included in minimising waste production at each step in the manufacturing process or during the use of a product. According to Abu Farha and Khraisheh (2008) this is the reduction process that can reduce the use of resources in terms of materials and energy, and also refers to activities that can reduce costs, waste and pollution. The practices of recycling and waste recovery activities mean that products are reprocessed and can be reused (Zain et al., 2011). Reuse refers to materials or products that are used repeatedly. Reusing items by improving the product can provide benefits to the community by selling them again and this can reduce waste and protect the environment (Hasnah, Dody, Noraziah, Maznah, \& Sarifah, 2012).

On the basis of the need to spread knowledge preservation to children, practice of the $3 \mathrm{Rs}$ among children should be implemented at the start of pre-school. Children easily accept an example if it is taught or shown by teachers and parents as this is an excellent example that must be followed or imitated. Teaching and learning methods that draw together tutoring have a clear desire to get more children to engage in $3 \mathrm{R}$ activities. Such activities with parents at home can make this practice more enjoyable $3 \mathrm{R}$ and children will be excited to continue to such preservation activities as part of their daily routine. 
Children need to be exposed in the environmental curriculum because of where they get their information, make decisions and then act on them (Mackey, 2012). Studies conducted prove that a child's ability to understand concepts and environmental issues often refers to older adults being able to learn more and also get counselling. Involvement of children in the study provides a new perspective when they voice their concerns. However, children cannot think rationally how their actions and involvement can help preserve the environment. Therefore, more adult responsibilities can be reinforced by giving explanations and fostering understanding to children on the reasons for their actions (Bates \& Regenza, 2007).

Reviews by Edwards and Cutter-Mackenzie (2011) found that children are still learning to recognise the signs at pre-school of recycling plastic bottles and disposing of products that have the recycling symbol. Sustainability practice habits can be nurtured in the preschool years in order to explain water conservation, the use of alternative energy sources, waste reduction and environmental awareness routinely every day at school. A pre-school in Australia, Hallett Cove, has been engaged in the practice of sustainability whereby the children will bring cans of soft drinks from home to put in the recycling bin, then sing songs about recycling. In addition, students in this school are taught about solid waste management, including putting banana peels into the compost bucket and putting yogurt containers into the recycling bin to be composted. Sustainability practices will continue as when other kids see these things they will also follow suit and make such activities part of their everyday practice.

Sustainability practices can also be fostered by creating a natural environment around the school by engaging in activities like raising chickens in the coop, farming, providing recycling bins or teaching children about the environment, which greatly helps to increase their knowledge. Children at Greytown Kindergarten in New Zealand were exposed to the real atmosphere of nature when they went camping in the woods in O'Connor's Bush Reserve. That program focuses on sustainability in a more realistic and practical way (Braithwaite, 2014). Ideas and suggestions for conserving practices in each preschool has the same equation and the ultimate success is when every child can practice these activities in everyday life, not only in school but also in their own homes.

Educating children in sustainable development was studied using the aspect of the child's gender. However, most studies found no significant difference between the knowledge of boys and girls in interpreting sustainability. Hulya (2011) showed that there were no differences between the genders in terms of attitudes. Environmental education can be applied in the family and in preschools according to gender itself. Concepts related to environmental impact are similar in both genders. The findings of Çabuk (2001) also support the finding of there being no gender differences in environmental studies conducted with preschool children in parallel with the present invention.

Moreover, a study on gender aspects in respect of the level of knowledge and awareness about sustainability issues was used in primary schools. Kaser (1992) found no significant differences in the level of environmental awareness among male and female students. The findings of Roslee et al. (2012) also showed no significant difference in environmental awareness among boys and girls. Hart (1978) examined the understanding of ecology and the 
level of information and attitudes towards the environment and found that there were significant differences among boys. As such, children should not be neglected when giving exposure to the preservation of nature. Regardless of gender or other demographic factors this is a phase that allows children to learn a variety of information.

\section{METHODOLOGY}

Cross sectional design was used in the survey method via a questionnaire. This study involved 500 MOE pre-school pupils in the district Hulu Langat, Selangor and used random sampling. Selected respondents were pupils aged 6 years and permission was received from the headmaster. The questionnaire for this study involved a variable called preservation of knowledge, which is knowledge of materials that both can and cannot be recycled. There were 10 items presented in the form of colour images. There was variable behaviour preservation involving 18 items: six items practiced Reduce, six were Reuse and six were Recycle. All items submitted for measuring the sustainability were in the form of colour images. A measurement scale used 2 = Always, $1=$ Sometimes and $0=$ Never. Construction of the display items was drawn by the situation and the environment in Malaysia. However, in previous studies a build item guide by Leeming, William and Bracken, (1995), who built the Children's Environmental Attitude and Knowledge Scale (CHEAKS) while other research (Ozturk, 2010) was used as the primary basis. This study uses descriptive and inferential statistical analysis to discuss the relationship between knowledge level and the preservation and practice of the 3 Rs.

\section{RESULTS AND DISCUSSION}

The pupils in the preschool KPM district were found to live in two different locations, namely urban preschools (250 respondents) (50\%) and rural (250) (50\%) and sampling techniques were used. This study involved 203 (40.6\%) male and female respondents, and 297 (59.4\%). Next in terms of race, a Malay total was 397 respondents $(79.4 \%)$, China's total was 44 respondents $(8.8 \%)$ and India numbered 59 respondents $(11.8 \%)$. The majority of respondents had received pre-school education by the age of 5 years, i.e. a total of 395 respondents (79.0\%), but 105 respondents $(21.0 \%)$ did not attend preschool by the age of 5 years (Table $1)$.

Table 1 Profile of Respondents

\begin{tabular}{llcc}
\hline Variable & & No. & $\%$ \\
\hline School Location & Urban area & 250 & 50.0 \\
& Rural area & 250 & 50.0 \\
Gender & Boy & 203 & 40.6 \\
& Girl & 297 & 59.4 \\
Race & Malay & 397 & 79.4
\end{tabular}




\begin{tabular}{llrc} 
& Chinese & 44 & 8.8 \\
& Indian & 59 & 11.8 \\
5 years old pre-school & Yes & 395 & 79.0 \\
pupils & No & 105 & 21.0 \\
\hline
\end{tabular}

\section{Knowledge of Recyclable and Non-recyclable Materials and Preschool Student Sustainability}

Analysis of continuity of knowledge about materials that can and cannot be recycled (Figure 1) shows the results (Table 2). Items that showed a low percentage of correct answers were glass bottles $(63.6 \%)$, followed by polystyrene food items $(50.8 \%)$ and the air box item (66.4\%). The highest percentages of correct items were those from a newsstand $(75.2 \%)$ followed by medicines $(73.4 \%)$ and $71.2 \%$ of raw foods.

Table 2 Materials Sustainability Knowledge can be recycled and can not be recycled

\begin{tabular}{lccccc}
\hline \multirow{2}{*}{ Items } & \multicolumn{2}{c}{ Non-Recyclable } & \multicolumn{2}{c}{ Recyclable } & Percentage \\
\cline { 2 - 4 } & No. & $\%$ & No. & $\%$ & True \\
\hline Drinking water & 168 & 33.6 & 332 & 66.4 & 66.4 \\
Raw Food & 356 & 71.2 & 144 & 28.8 & 71.2 \\
Glass Bottle & 182 & 36.4 & 318 & 63.6 & 63.6 \\
Toxic Material & 353 & 70.6 & 147 & 29.4 & 70.6 \\
Boxes & 147 & 29.4 & 353 & 70.6 & 70.6 \\
Polystyrene & 254 & 50.8 & 246 & 49.2 & 50.8 \\
Aluminums cans & 162 & 32.4 & 338 & 67.6 & 67.6 \\
Medications & 367 & 73.4 & 133 & 26.6 & 73.4 \\
Newspapers & 124 & 24.8 & 376 & 75.2 & 75.2 \\
Stones & 339 & 67.8 & 161 & 32.2 & 67.8 \\
\hline
\end{tabular}

\section{Sustainability Knowledge}

Match the ingredients below whether it can be recycle or non-recyclable materials

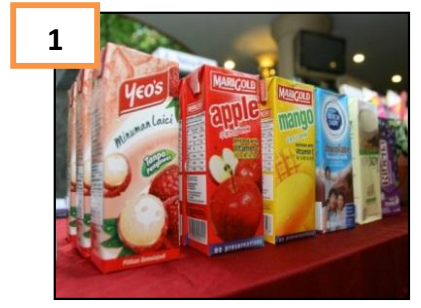

Drinking water

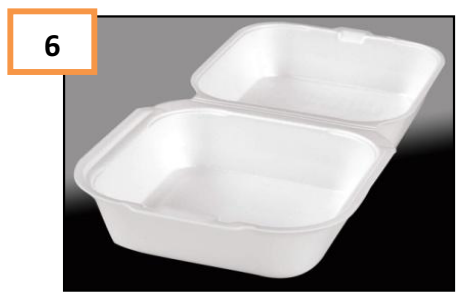

Polystyrene 


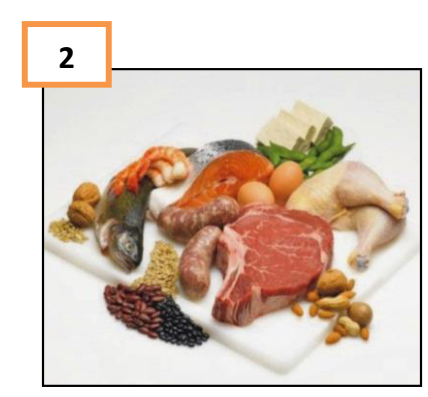

Raw Foods

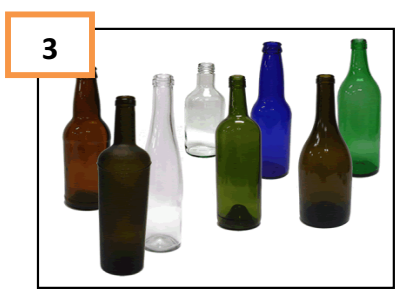

Glass Bottles

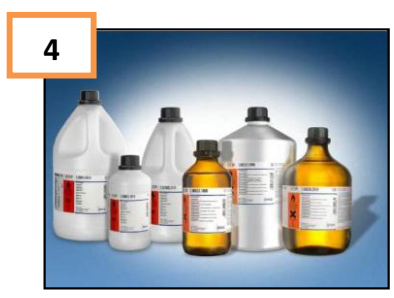

Toxic Materials

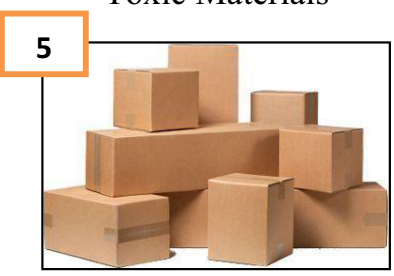

Boxes
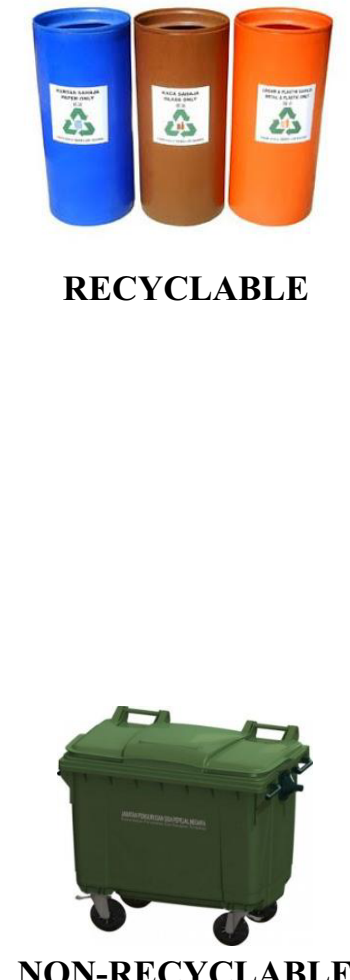

NON-RECYCLABLE

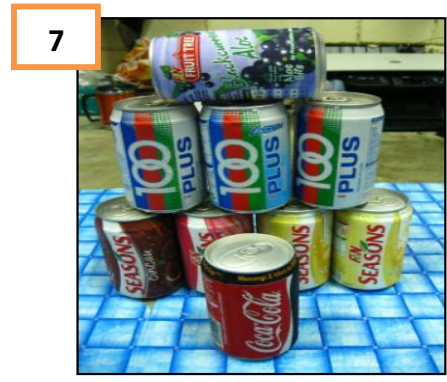

Aluminums Cans

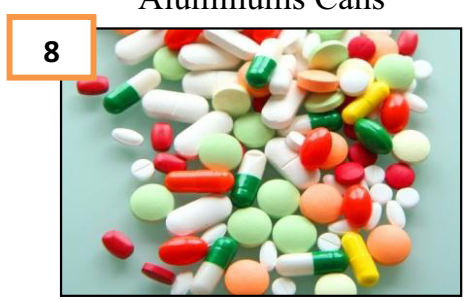

Medications

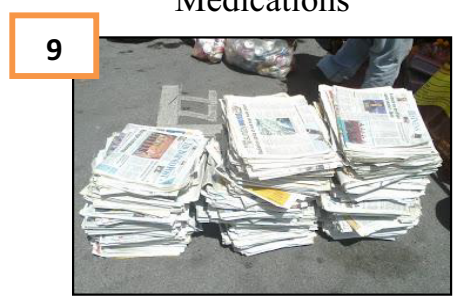

Newspapers

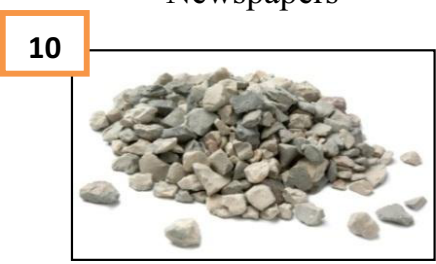

Stones

Figure 1: Match Recyclable and Non-Recyclable Materials

The results of the analysis in terms of the level of knowledge of materials (Table 3 ) among respondents showed a moderate score range (1:01 to 2:00), with about 61 of them $(12.2 \%)$ and at high levels (scores range 2:01 to 3:00) a total of 439 respondents (87.8\%). Obviously the level of knowledge of materials which can and cannot be recycled recycled among respondents was high $($ mean $=2.87, \mathrm{SD}=0.32)$. Next the variables of sustainability practices involved the $3 \mathrm{R}$ practice of 18 displayed items. Based on Table 3 , the variables of sustainability practices at a low level (score range $0.00-0.66$ ) showed a total of 41 patients (8.2\%), moderate (score range 1:01 to $2: 00)$ to about 350 people $(75.0 \%)$ and at high levels 
(range score 2:01 to 3:00) a total of 109 respondents $(21.8 \%)$. This clearly shows that the level of sustainability practices among respondents was moderate $($ Mean $=2.13, \mathrm{SD}=0.53$ ).

For sub variables of sustainability practices (Table 3 ), i.e. a practice of the Reduce level of low-level (score range $0.00-0.66)$ were 62 respondents $(12.4 \%)$, moderate (score range 1:01 to 2:00), about 410 people (82.0\%) and at high levels (scores range 2:01 to 3:00) of 28 respondents $(5.6 \%)$. Obviously the level of sustainability practices among respondents was moderate $($ Mean $=1.93, \mathrm{SD}=0.41)$. Next to Recycle practices at the level of the low level (score range $0.00-0.66)$ were a total of 151 respondents $(30.2 \%)$, moderate (score range 1:01 to 2:00) $210(42.0 \%)$ and at high levels (scores range 2.01-3.00) and 139 people $(27.8 \%)$. Obviously the level of sustainability practices among respondents was moderate (Mean = $1.97, \mathrm{SD}=0.76$ ). Finally, the Reuse practices at the level of the low level (score range 0.00 0.66 ) were a total of 89 respondents $(17.8 \%$ ), moderate (score range 1:01 to 2:00), a total of 275 respondents $(55.0 \%$ ) and at high levels (scores range 2.01-3.00) and a total of 136 respondents $(27.2 \%)$. Clearly the level of Reuse practices among respondents was moderate $($ Mean $=2.09, \mathrm{SD}=0.66)$.

The study found that the behavior of sustainability involving Reduce, Recycle and Reuse is at a moderate level. Lampa et al., (2013), explains that instructional strategies in the classroom teachers more focus on learning through simulation and experiments and less involved case studies of implications on student behavior. This has led to less effective implementation of sustainable development through education in schools. Reviews by Agut et al. (2014) has pointed out that sustainability disclosure rules must be in a complete and clear disclosure of the knowledge and hands-on practice of conservation activities in the study of pre-school students is requirement. Studies also mention that teacher have the important role about sustainability (Eriksen, 2013; Eva 2013; Samuelsson and Kaga, 2010). Focus on improving behavior among students will provide a positive impact (Edwards \& Moore, 2012) and the positive impact of these behaviors can be practiced outside of the school especially with family members (Bates and Tregenza, 2007; Braithwaite, 2014).

Table 3 Level of Variables Knowledge, and Practice Student 3Rs in Preschool

\begin{tabular}{|c|c|c|c|c|c|c|c|c|c|}
\hline \multirow[t]{2}{*}{ Variable } & \multicolumn{2}{|c|}{ Low Level } & \multicolumn{2}{|c|}{$\begin{array}{l}\text { Medium } \\
\text { Level }\end{array}$} & \multicolumn{2}{|c|}{ High Level } & \multirow[t]{2}{*}{ Mean } & \multirow[t]{2}{*}{ SD } & \multirow[t]{2}{*}{$\begin{array}{l}\text { Mean } \\
\text { Level }\end{array}$} \\
\hline & $\mathrm{N}$ & $\%$ & $\mathrm{~N}$ & $\%$ & $\mathrm{~N}$ & $\%$ & & & \\
\hline $\begin{array}{l}\text { Material } \\
\text { Knowledge }\end{array}$ & 0 & 0 & 61 & $\begin{array}{r}12 . \\
2\end{array}$ & 439 & 87.8 & 2.87 & 0.32 & High \\
\hline 3R Practices & 41 & 8.2 & 350 & $\begin{array}{r}70 . \\
0\end{array}$ & 109 & 21.8 & 2.13 & 0.53 & $\begin{array}{l}\text { Mediu } \\
\mathrm{m}\end{array}$ \\
\hline - Reduce & 62 & $\begin{array}{r}12 . \\
4\end{array}$ & 410 & $\begin{array}{r}82 . \\
0\end{array}$ & 28 & 5.6 & 1.93 & 0.41 & $\begin{array}{l}\text { Mediu } \\
\mathrm{m}\end{array}$ \\
\hline - Recycle & 151 & $\begin{array}{r}30 . \\
2\end{array}$ & 210 & $\begin{array}{r}42 . \\
0\end{array}$ & 139 & 27.8 & 1.97 & 0.76 & $\begin{array}{l}\text { Mediu } \\
\mathrm{m}\end{array}$ \\
\hline
\end{tabular}




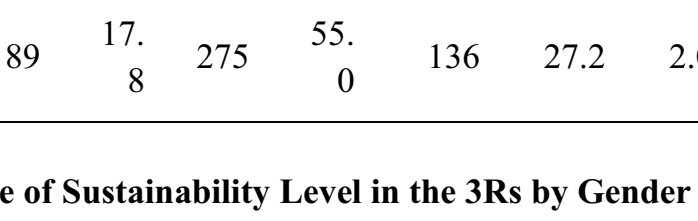

The results of the test between variables of crosstabs reducing the level of practice and gender (Figure 2) clearly shows the high level, whereby female respondents numbered higher percentages of $3.2 \%$ (16 patients) compared with $2.4 \%$ of male respondents (12 people). Similarly, in reducing practice at a moderate level, $49.4 \%$ of female respondents ( 247 people) were more than male respondents, which was $32.6 \%$ (163 people). Crosstabs test between the variable stages of recycle practices and gender (Figure 2) clearly shows the high level, with female respondents being higher percentages of $17.6 \%$ (88 patients) compared with $10.2 \%$ of male respondents (51 people). Similarly, a Reduce practice at a moderate level numbered $25.8 \%$ of female respondents (129 people), which was more than male respondents, i.e. $16.2 \%$ (81 patients). At low levels, $16.0 \%$ of female respondents (80 people) and $14.2 \%$ of male respondents ( 71 people). Next crosstabs test results between variables phase recycle practices and gender (Table 6) clearly shows the high level, with female respondents numbering higher percentages of $3.2 \%$ (16 patients) compared with $2.4 \%$ of male respondents (12 people). Similarly, Reduce practice at a moderate level showed $49.4 \%$ of female respondents (247 people), which was more than male respondents, $32.6 \%$ (163 people).

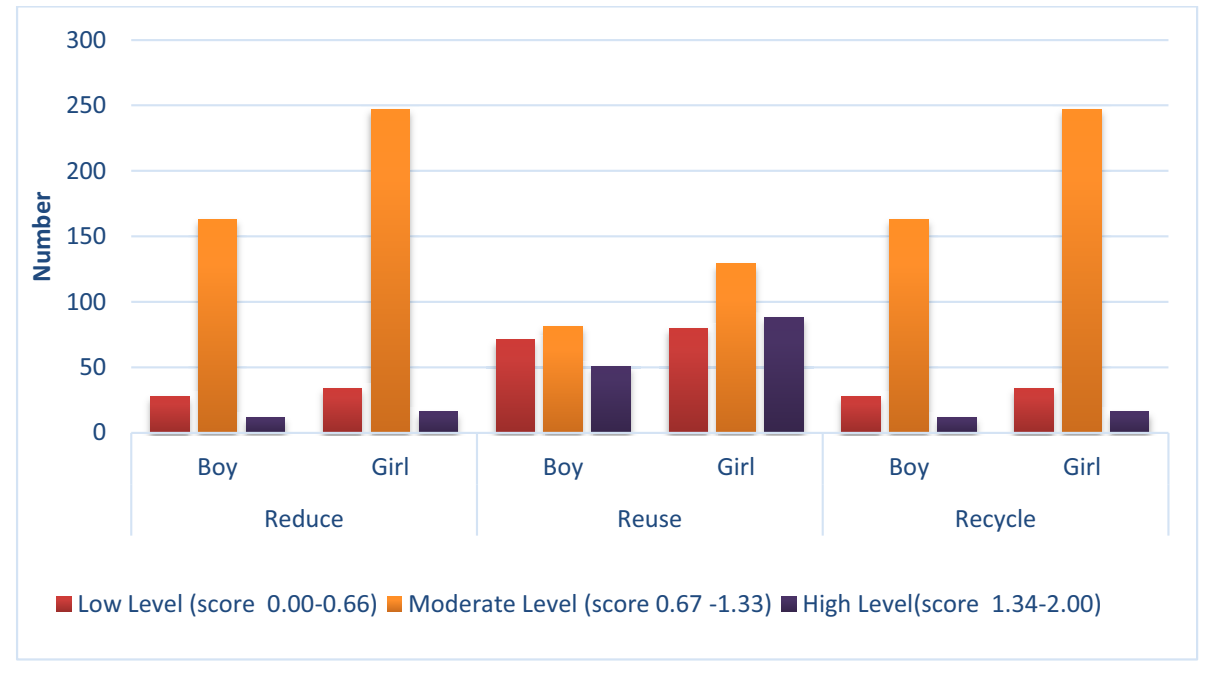

Figure 2: Practice Stage 3R by Gender

\section{Knowledge Sustainability Variables Relationship with 3R Practice}

The results of the correlation matrix analysis in Table 4 show that there is no relationship between the variables knowledge and practice of the $3 R s(r=.007 ; \mathrm{P}>0.05)$. This finding is somewhat alarming if sustainability practices cannot be formed in early childhood. The study 
relates that a positive attitude to environmental ethics is intertwined with knowledge of early childhood interaction with nature (Chawla, 1988). Creating awareness of the environment among the public takes a long time. It should be nurtured since childhood and continue until people reach the age of maturity. This process should not stop there, but instead continue until the person really understands and realises the importance of preserving and conserving the environment (Roslee et al., 2012). The existence of the mass media, video games, computer activities, and communication through social networks via the telephone and internet, has become a trend nowadays and develops the minds and imagination in children. They are taught knowledge preservation unofficially via the programs of environmental education through the media and this can have a positive impact on the environment and also benefit their learning.

\section{CONCLUSION}

The final assessment of the level of knowledge and behaviour of preschool pupils in the 3Rs demonstrates that sustainability practices are not yet at a level that we can be proud of. Conservation and $3 \mathrm{R}$ practices are still less applied among respondents. The application of $3 \mathrm{R}$ in practice also exists among more girls than boys. This explains that continuity of knowledge and information preservation has not become a habit. Previous studies examine the positive relationship with behaviours or knowledge preservation practices. This study reveals that attention should be given to increasing the level of $3 \mathrm{R}$ practices to all pupils in preschool. Diversity conservation practices through such activities via $3 \mathrm{R}$ practices are a necessity. $3 \mathrm{R}$ practice should not just exist on paper but also be part of activities with pupils.

\section{ACKNOWLEDGEMENTS}

Author would like to thank Universiti Pendidikan Sultan Idris through the Centre for Research and Innovation (RMIC) for awarding University Research Grant (GPU), code 2014-0054106-01 research.

\section{REFERENCES}

Abu Farha, F. K., \& Khraisheh, M. K. (2008). An Integrated Approach to the Superplastic Forming of Lightweight Alloys: Towards Sustainable Manufacturing. International Journal of Sustainable Manufacturing, 1,18-40.

Agut, M. P. M., Ull, M. A., \& Minguet, P. A. (2014). Education for sustainable development in early childhood education in Spain. Evolution, trends and proposals. European Early Childhood Education Research Journal, 22(2), 213-228.

Aini, M. ., \& Laily, P. (2010). Preparedness of Malaysian Pre-school Educators for Environmental Education. Pertanika Journal of Social Sciences \& Humanities, 18(2), 271-283. 
Bates, S. \& Tregenza, N. (2007). Education for Sustainability in the Early Years: A Case Study from Hallett Cove Preschool. Australian Sustainable Schools Initiative: South Australia

Braithwaite, D. (2014). 'One nearly on finger': A forest kindergarden in rural New Zealand. Journal of Teachers' Work, 11 (1), 3-16.

Çabuk, B. (2001). Environmental awareness level of preschool children. Ankara University. Turkey.

Chawla, L. (1988). Childrenís concern for the natural environment. Childrenis Environments Quarterly, 5(3), 13-20.

Frank C. Leeming, William O’Dwyer \& Bruce A. Bracken (1995). Children's Environmental Attitude and Knowledge Scale (CHEAKS).

Davis, J. M. (2009). Revealing the research "Hole" of early childhood education for sustainability: A preliminary survey of the literature. Education for Environmental Education Research, 15(2), 227-241.

Edwards, S \& Cutter-MacKenzie (2011). Environmentalising early childhood education curriculum through pedagogies of play. Australasian Journal of Early Childhood, vol. 36 , no. 1 , pp. 51-59.

Eriksen, K. G. (2013). Why education for sustainable development needs early childhood education: the case of Norway. Journal of teacher Education for Sustainability, $14(1), 107-120$

Ernst, J. (2007). Factors associated with K-12 teachers' use of environment-based education. Journal of Environmental Education, 38(3), 15-32.

Eva, A. H. (2013). Respect for - nature a prescription for developing awareness in preschool. CEPS Journal, 3(1), 25-44

Hägglund, S., \& Samuelsson, I. P. (2009). Early childhood education and learning for sustainable development and citizenship. International Journal of Early Childhood, 41(2), 49-64.

Hanifah. (2013). Awareness And Commitment Towards Education For Sustainable Development In School Communities. Universiti Pendidikan Sultan Idris.

Hart S. (1978). Beyond greening: strategies for a sustainable world. Harvard Business.Review 2000:66-76

Hasnah, A., Dody, D., Noraziah, A., Maznah, I., \& Sarifah, Y. (2012). Community and solid waste management practices towards community sustainability: The case of household women in Bandar Baru Bangi, Malaysia. Malaysia Journal of Society and Space, (5), $64-75)$.

Hopkins, C. \& McKeown, R. (2002). Environment education for sustainability: Responding to the global challenges. In D. G. Tilbury, D. Stevenson, R.B., Fien, J. \& Schreuder (Ed.), . U.K.: IUCN Commission on Education and Communication.

Hülya, G. (2011). Reliability and Validity Studies of the Turkish Version of the Children's Attitudes toward the Environment Scale-Preschool Version (CATES-PV) and the Analysis of Children's Pro-environmental Behaviors According to Different Variables. Asian Social Science, 7(10), 231-240.

Glenn, J. L. (2000). Environment-based education: Creating high performance schools and students. Washington, DC: NEETF. 
Johansson, E. (2009). The preschool child of today - The world-citizen of tomorrow? International Journal of Early Childhood, 41(2), 79-96.

Joshi, U. (2009). Education for Sustainable Development-The Role of University. In International Forum of Teaching and Studies Marietta (pp. 62-69).

Kaseri, S. (1992). The relationship between the level of environmental awareness and the level of cognitive development among secondary school students in the state of Selangor. Bangi: Faculty of Education.

Lampa, I. Greculescu, A. \& Todorescu (2013). Education for Sustainable Development Training the Young Generation for the Future. Social and Behavioral Sciences 78120 $-124$

Leeming, F. ., William, O., \& Bracken, B. . (1995). Scale, Children's Environmental Attitude and Knowledge (CHEAKS). The Journal of Environmental Education, 26(3), 22-32.

Lieberman, G., \& Hoody, L. (1998). Closing the achievement gap: Using the environment as an integrating context for learning. San Diego, CA: State Education and Environmental Roundtable.

Louv, R. (2005). Last child in the woods: Saving our children from nature-deficit disorder. Chapel Hill, NC: Algonquin Books

Ministry of Education. (2010). National Preschool Curriculum: National Standard Curriculum for Preschool 2010. Putrajaya: Curriculum Development Centre.

Md Zain, S., Ahmad Basri, N. E., Basri, H., Zakaria, N., Elfithri, R., Ahmad, M.,Istear Khan, I. A. (2011). Recycling Practices concerns on sustainability attitudes and behaviors. Proceeding on Education Engineering \& the Built Environment (PeKA'11) Congress Teaching and Learning UKM, 421-435.

Mackey, A. (2012). Input, interaction and corrective feedback in L2 classrooms. Oxford: Oxford University Press.

Martinez Agut M. P., Ull M. A., and Minguet P. A. (2014).Education for sustainable development in early childhood education in spain. Evolution, trends and proposals. European $n$ Early Childhood Education Research Journal, Vol. 22, No. 2, 213-228

Mohmadisa Hasyim, \& Mohamad Suhaily Yusri Che Ngah (2010). Development and Environment in Malaysia. Tanjong Malim Perak: Universiti Pendidikan Sultan Idris.

Moroye, C.(2005). Common ground : An ecological Perspective on teaching and learning. Curriculum and Teaching Dialogue, 7(1/2), 123-139.

Özturk, D. . (2010). Preschool children's attitudes towards selected environmental issues. Middle East Technical University.

Palmer, J. A. (1995). Environmental thinking in the early years. Understanding and misunderstanding of concepts related to waste management. Environmental Education Research, 1(1), 35-45.

Palmer, J.A., Suggate, J., Bajd, B. \& Tsaliki, E. (1998). Significant Influences on the Development of Adult's Environmental Awareness in the UK, Slovenia and Greece. Environmental Education Research, Vol.4, No. pp.429 - 464 Oxford Carfax

Roslee, T., Dg. Norizah, A. K., Soon Singh, B. S., \& Muniandy, S. (2012). Environmental Education and Its Relationship with the knowledge and Environmental Awareness Among Secondary School Students in Urban and Rural Areas in Tawau. Pendidikan Alam Sekitar : Melestarikan Kesedaran Masyarakat Di Malaysia. 
Salonen A. O. dan Tast S. (2013). Finnish Early Childhood Educators Sustainable Development. Journal of Sustainable Development; 6 (2); 2013

Samuelsson I. P. (2011). Why we should begin early with ESD: The role of early childhood education. Department of Education, Communication and Learning, University of Gothenburg.Springer Science+Business Media B.V. 43: 103-118.

Samuelsson, I. P., \& Kaga, Y. (2010). Early childhood education in transforming cultures forsustainability. In E. Assadourian (Ed.), State of the World 2010. Transforming cultures: $\quad$ From consumerism to sustainability.Washington:Worldwatch Institute.pp.57-61

Scoullos, M., \& Malotidi, V. (2004). Handbook on methods used in environmental education and education.Athens:MIO-ECSDE.Retrievedfrom http://www.medies.net/_uploaded_files/publications/HANDBOOK._ENGpdf.pdf

Siraj-Blatchford, J. (2009). Editorial: Education for sustainable development in early childhood. International Journal of Early Childhood, 41(2), 9-22.

Siti Aminah, M., Rainah, G., \& Cynthia A, R. D. (2009). Residents Consciousness Studies UiTM Campus Kota Kinabalu Against Waste Reduction. UiTM. Publisher.

Sterling, S. (2003). Whole Systems Thinking as a Basis for Paradigm Change in Education: Explorations in the context of sustainability. University of Bath.

Tilbury, D., Stevenson, R., Fein, J., Schreuder, D. (2002). Education and sustainability responding to the global challeng. International Union for Conservation of Nature and Natural Resources (p. 6). Gland.

UNESCO (2012). Education for sustainable development good practices in early childhood. Perancis. 